\title{
Effect of Vitamin E Supplementation on Some Minerals in Diabetic Rats
}

\author{
Hoda S. Ibrahim*, Zahraa E. Sayed, and Hany G. El Masry \\ Nutrition and Food Science Dept., Faculty of Home Economics, Helwan University Cairo, Egypt \\ *Corresponding Author: Hoda S. Ibrahim, Nutrition and Food Science Dept., Faculty of Home \\ Economics, Helwan University Cairo, Egypt, E-mail: Dr_Hoda_Salama@hotmail.com
}

\begin{abstract}
The present study was carried out to investigate the effect of vitamin E supplementation on some minerals (phosphors, calcium and iron) in diabetic rats. Thirty adult male albino rats were divided into 5 groups ( $n=6$ rats). The first normal group was fed on the basal diet and considered as a negative control group.The rest of the animals (24 rats) were injected with alloxan to induce diabetes and divided to groups from 2-5. The second group (positive control) was diabetic and was fed on the basal diet. Groups 3- 5 were diabetic and were fed on basal diets supplemented with vitamin E at three levels of intake $(0.75 \%, 1 \%$ and $1.5 \%$, respectively). During experiment (7 weeks) food intake, body weight gain, glucose, phosphors, calcium and iron in the blood as well as in bone of the tested rats were determined. At the end of the experiment rats were scarified, for serum collection. Results revealed that rats fed on vitamin $E$ at the three tested levels showed significant reduction in serum glucose levels. Also, results showed that vitamin E supplementation at level $0.75 \%$ had significant increase in the concentration of phosphorus, calcium and iron in bone of diabetic rats. The histopathological results showed that supplementation with vitamin E at high levels may cause some problems in liver and kidney tissues. It can be concluded that vitamin $E$ at the tested levels could be used as a suitable supplementation for diabetic patients and bone metabolism.
\end{abstract}

Keywords: Diabetic rats - Vitamin E-Serum glucose- Serum Calcium-Feed intake

\section{INTRODUCTION}

Diabetes mellitus is a group of metabolic diseases in which a person has high blood sugar, either because the body does not produce enough insulin, or because cells do not respond to the insulin that is produced in the body (Rother, 2007). This high blood sugar produces the classical symptoms of polyuria, polydipsia and polyphagia. This Symptoms may develop rapidly in type 1 diabetes, while in type 2 diabetes they usually develop much more slowly and may be subtle or absent. Diabetes mellitus is manifested in three primary forms: Type1 diabetes, Type2 diabetes and gestational diabetes (Wild et al., 2004).

Human body regulates blood glucose to maintain an adequate supply of glucose for cells. Two hormones produced by the pancreas tightly control blood glucose levels when its levels rise after a meal. The pancreas releases the insulin hormone into the blood, Insulin acts like a key unlocking the cells of the body and allowing glucose to enter and fuel. Insulin also stimulates liver and muscle cells to store glucose as glycogen, when individual has not eaten in a while and blood glucose levels begin to fall. The pancreas releases another hormone called glucagon which stimulates the body to break down stored glycogen, releasing glucose into the bloodstream when blood glucose level decreased. Glucagon also stimulates the synthesis of glucose from protein (Risérus et al., 2009).

Antioxidants such as vitamin E act to protect the cells against the effects of free radicals, which are potentially damaging by-products of energy metabolism. Free radicals can damage cells and may contribute to the development of cardiovascular disease and cancer. Studies are underway to determine whether vitamin $\mathrm{E}$, through its ability to limit production of free radicals, might help prevent or delay the development of those chronic diseases. Vitamin $\mathrm{E}$ has also been shown to play a role in immune function, in DNA repair, and other metabolic processes (Traber and Packer, 1995).

Vitamin $\mathrm{E}$ is an essential nutrient for the human body needs to function normally. The term vitamin E actually represents a group of substances, the most important being alphaPage |19 
tocopherol. The main sources of vitamin $\mathrm{E}$ in the diet are vegetable oils (especially safflower oil, sunflower oil and cottonseed oil), green leafy vegetables, nuts, cereals, meats, egg yolks, wheat germ, and whole wheat products (Herrera and Barbas, 2001; Ball,2004).

Diabetes mellitus induces alterations in bone and mineral metabolism. Diabetic bone disorder causes an increase in bone fractures, delays healing of fractures, and affects the quality of life. There are few optimal therapies for these disorders and the mechanisms responsible for their complications have not been clearly identified. Bone histology studies in humans and animals have demonstrated that decreased bone formation is a critical mechanism of bone mass reduction in diabetes (Hamada et al., 2009). From few bone histology studies in humans and experimental studies there is evidence that a decreased bone formation is one major mechanism leading to reduced bone mass in diabetics (Van Campenhout et al.2006). The metabolism of several essential elements is altered in diabetes mellitus and these nutrients might have specific roles in the pathogenesis and progress of this disease, nevertheless, the mechanisms are still far from known (Halliwell et al.,2005). Thus the present study was carried out to investigate the effect of vitamin $\mathrm{E}$ supplementation on some minerals in diabetic rats.

\section{Materials AND MethodS}

Animals: Male albino rats $(\mathrm{n}=30)$ weighing $(95.00 \pm 5.00 \mathrm{~g})$ of Sprague Dawley strain were obtained from the Laboratory Animals Colony, Ministry of Health and Population, Helwan, Egypt.

\subsection{Materials}

\subsubsection{Chemicals}

Casein, vitamins mix, minerals mix, vitamin $\mathrm{E}$, cellulose, choline and alloxane were obtained from El-gomhoria Company for pharmaceutical and chemicals, Cairo, Egypt. Kits for biochemical analysis were being obtained from Gamma Trade Company for pharmaceutical and chemicals, Dokki, Egypt.

\subsection{Methods}

\subsubsection{Diet Composition and Experimental Animal Design}

Basal diet for rats was prepared according to the AIN 93-M according to Reeves et al., 1993. Vitamin E (dl-alpha-tocopherol acetate) was added at three levels of intake $(0.75 \%, 1 \%$, and
$1.5 \%)$ over the basal diet as a supplement. The present experiment was done in the animal house, Faculty of Home Economics, Helwan University, Cairo, Egypt. Animals were housed in a normal healthy condition and allowed water was available. After two weeks of adaptation, rats were divided into groups as follows: The first group was fed on basal diet and served as a negative control group (-ve). The rest of the animals (24) were injected with alloxan for diabetes induction then divided to groups. The second group (positive control) was diabetic and was fed on the basal diet. Groups 3-5 were diabetic and were fed on basal diets supplemented with vitamin $\mathrm{E}$ at three levels of intake $(0.75 \%, 1 \%$ and $1.5 \%$, respectively). At the end of the experimental period (7 weeks), rats were sacrificed and blood samples were collected then centrifuged to separate the serum and kept frozen at $-20 \mathrm{oC}$ till analysis.

\subsubsection{Biological Determination}

Biological determination was carried out by determination of feed intake (FI) which was calculated every day throughout the experimental period. Over all body weight gain (BWG), feed efficiency ratio and organs relative weight were determined according to (Chapman et al., 1959).

\subsubsection{Biochemical Analysis}

Serum glucose was determined according to (Kaplan et al., 1984 and Trinder, 1969). Serum $\mathrm{Ca}$ concentration was determined according to (Gindler and king, 1972). Serum phosphorus concentration was determined according to (Elmerzabani et al., 1977). Serum Iron concentration was determined according to (Dreux, 1977).

\subsubsection{Histopathological Examination}

Specimen from liver and kidney were taken immediately after sacrificing the rats and immersed in $10 \%$ formalin solution. The fixed specimens were then trimmed, washed and dehydrated in ascending grades of alcohol. They were cleared in xybl, embedded in paraffin, sectioned at 4-6 micron thickness and stained with Heamtoxylin and Eosin according to Carleton (1979). The histopathological examination was carried out at Pathology Department, Faculty of Agriculture and Cairo University.

\section{STATisticalanalysis}

Results of biochemical analysis and biological evaluation of each group were statistically 
analyzed as mean \pm SE using one-way ANOVA as described by SAS, (2006).

\section{RESUltS AND DISCUSSION}

Results in Table (1) indicate the effect of different levels of vitamin $\mathrm{E}$ on feed intake (FI), body weight gain (BWG) and feed efficiency ratio (FER) of diabetic rats. Data show that when rats were injected with alloxan $(+v e)$ control group, their mean value of feed intake was increased with a mean value of $14.54 \pm 0.55$ $\mathrm{g} / \mathrm{d}$ compared to the (-ve) control group which fed on basal diet only $(11.55 \pm 0.46 \mathrm{~g} / \mathrm{d})$.
This increase was not significantly different. However, when rats were ingested diet supplemented with vitamin $\mathrm{E}$, feed intake was reduced significantly at the lowest two levels of intake $(0.75$ and $1 \%)$.

Concerning body weight gain (BWG) of diabetic rats, results in Table (1) showed the same trend of feed intake (FI).In the diabetic control group, BWG was increased with a mean value of $0.94 \pm 0.09 \mathrm{~g}$ compared to the normal rats with mean value of $0.70 \pm 0.13 \mathrm{~g}$.

Table1. Effect of Feeding Different levels of Vitamin E on Feed intake (FI), Body Weight Gain (BWG) and Feed Efficiency Ratio (FER) of Diabetic Rats.

\begin{tabular}{|c|c|c|c|c|}
\hline \multicolumn{2}{|c|}{ Groups } & $\underset{(g / d)}{\text { Feed intake (FI) }}$ & $\underset{(\mathrm{g} / \mathrm{d})}{\operatorname{Body} \text { Weight Gain (BWG) }}$ & $\underset{(\mathbf{g} / \mathbf{d})}{\text { Feed Efficiency Ratio (FER) }^{(2)}}$ \\
\hline \multirow{2}{*}{$\begin{array}{l}\overline{0} \\
\bar{E} \\
\bar{E}\end{array}$} & $\begin{array}{c}\text { Group(1) } \\
(-v e)\end{array}$ & $\begin{array}{c}\mathrm{ab} \\
11.55 \pm 0.46\end{array}$ & $\begin{array}{c}\mathrm{b} \\
0.70 \pm 0.13\end{array}$ & $\begin{array}{c}c \mathrm{c} \\
0.04 \pm 0.01\end{array}$ \\
\hline & $\begin{array}{c}\text { Group(2) } \\
(+\mathrm{ve})\end{array}$ & $\begin{array}{c}\mathrm{a} \\
\text { 14. } 54 \pm 0.55\end{array}$ & $\begin{array}{c}\mathrm{a} \\
0.94 \pm 0.09\end{array}$ & $\begin{array}{c}\mathrm{a} \\
0.07 \pm 0.02\end{array}$ \\
\hline \multirow{3}{*}{ 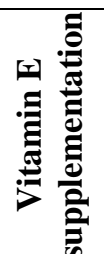 } & $\begin{array}{c}\text { Group(3) } \\
0.75 \%\end{array}$ & $\begin{array}{c}c \mathrm{c} \\
6.09 \pm 1.59\end{array}$ & $\begin{array}{c}c \\
0.65 \pm 0.12\end{array}$ & $\begin{array}{c}c c \\
0.04 \pm 0.03\end{array}$ \\
\hline & $\begin{array}{c}\text { Group(4) } \\
1 \% \\
\end{array}$ & $\begin{array}{c}\mathrm{d} \\
4.02 \pm 1.85\end{array}$ & $\begin{array}{c}\mathrm{d} \\
0.42 \pm 0.17\end{array}$ & $\begin{array}{c}\mathrm{ab} \\
0.06 \pm 0.01\end{array}$ \\
\hline & $\begin{array}{c}\text { Group(5) } \\
1.5 \%\end{array}$ & $\begin{array}{c}\mathrm{ab} \\
12.70 \pm 1.15\end{array}$ & $\begin{array}{c}\mathrm{ab} \\
0.82 \pm 0.10\end{array}$ & $\begin{array}{c}\mathrm{ab} \\
0.06 \pm 0.02\end{array}$ \\
\hline
\end{tabular}

Results of this study indicated that, feed intake (FI), body weight gain (BWG) and feed efficiency ratio (FER) of diabetic rats showed significant increase compared to the (-ve) control group which fed on basal diet. This increases in feed intake could be explained on the basis of glucose, which is the energizer of the cells, remains at the entrance of the cells but can't get through it .This condition leads to excess of hunger as stated by Aruoma et al., 2007. Also, as a result of increasing FI the BWG was increased this could be explained by converting the excess of glucose to fat in the body.

Vitamin E supplementation at the lowest two levels produced reduction in feed intake, body weight gain and feed efficiency ratio in this study. Our results were in accordance with Devereux et al., 2006 who reported that rats treated with vitamin $\mathrm{E}$ had higher body weight compared to the control group. However, results of this study were disagreed with those of Hayward et al, 1992 who found no difference in feed intake and body weight gain among all tested groups. These differences between these findings and our results could be explained with the difference in the type of the tested animals, tested doses as well as the duration of the experiment.

Results show the effect of different levels of vitamin $\mathrm{E}$ on liver, heart and kidney relative weight of diabetic rats are presented in Table (2), the results revealed that the control group (fed on basal diet) had liver relative weight of $2.57 \pm 0.016 \%$. When rats were become diabetic (+ve control) showed significant reduction in relative liver weight $2.04 \pm 0.02 \%$. However, when rats were supplemented with vitamin $\mathrm{E}$ at $0.75 \%$, liver relative weights were increased with a mean value of $2.53 \pm 0.03 \%$ compared to the control groups.

Concerning heart relative weight, data showed that the highest value was seen with the group of rats supplemented with $0.75 \%$ vitamin $\mathrm{E}$ in the diet $(0.34 \pm 0.01 \%)$, while the lowest value was seen with the diabetic rats fed on the basal diet with vitamin supplementation (+ve control). Also, results showed that kidneys relative weight for groups of rats ingested vitamin $\mathrm{E}$ at any levels of intake were increased significantly compared to the + ve control group $(0.56 \pm 0.01$ $\%, 0.58 \pm 0.02 \%, 0.54 \pm 0.01 \%$ and $0.52 \pm 0.03 \%$, respectively). 
Table2. Effect of Different Levels of Vitamin E on Liver, Heart and Kidney Relative Weight of Diabetic Rats

\begin{tabular}{|c|c|c|c|c|}
\hline \multirow{2}{*}{\multicolumn{2}{|c|}{ Groups }} & \multicolumn{3}{|c|}{ Relative Organ Weight \% } \\
\hline & & Liver & Heart & kidney \\
\hline \multirow{2}{*}{ } & $\begin{array}{c}\text { Group(1) } \\
\text { (-ve) }\end{array}$ & $\begin{array}{c}\mathrm{a} \\
2.57 \pm 0.01\end{array}$ & $\begin{array}{c}c \mathrm{c} \\
0.27 \pm 0.01\end{array}$ & $\begin{array}{c}\mathrm{a} \\
0.82 \pm 0.01\end{array}$ \\
\hline & $\begin{array}{c}\text { Group(2) } \\
(+v e)\end{array}$ & $\begin{array}{c}\mathrm{d} \\
2.04 \pm 0.02\end{array}$ & $\begin{array}{c}\mathrm{d} \\
0.25 \pm 0.02\end{array}$ & $\begin{array}{c}\mathrm{d} \\
0.52 \pm 0.03\end{array}$ \\
\hline \multirow{3}{*}{ 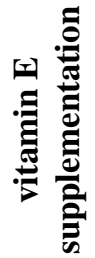 } & $\begin{array}{c}\text { Group(3) } \\
0.75 \%\end{array}$ & $\begin{array}{c}\mathrm{a} \\
2.53 \pm 0.03\end{array}$ & $\begin{array}{c}\mathrm{a} \\
0.34 \pm 0.01\end{array}$ & $\begin{array}{c}\mathrm{bc} \\
0.56 \pm 0.01\end{array}$ \\
\hline & $\begin{array}{c}\text { Group(4) } \\
1 \%\end{array}$ & $\begin{array}{c}c \\
c \\
2.25 \pm 0.03\end{array}$ & $\begin{array}{c}\mathrm{b} \\
0.32 \pm 0.01\end{array}$ & $\begin{array}{c}\mathrm{b} \\
0.58 \pm 0.02\end{array}$ \\
\hline & $\begin{array}{c}\text { Group(5) } \\
1.5 \%\end{array}$ & $\begin{array}{c}\mathrm{b} \\
2.41 \pm 0.04\end{array}$ & $\begin{array}{c}\mathrm{b} \\
0.31 \pm 0.02\end{array}$ & $\begin{array}{c}c \\
0.54 \pm 0.01\end{array}$ \\
\hline
\end{tabular}

* Mean values are expressed as means $\pm \mathrm{SE}$. Means with different superscript letters in the column are significantly different at $(\mathrm{P}<0.01)$.

Concerning organs relative weight, data of the present study revealed that liver, heart and kidneys relative weight of diabetic rats were decreased significantly as a result of diabetic induction compared to the -ve control group. However, when diet was supplemented with vitamin $\mathrm{E}$ caused increase in organ relative weights.

The increase in organs relative weight could be attributed to the injured structural integrity of these organs after cellular damages by the effect of alloxan injection. The obtained results was in agreement with those of EL-Miedany et al.,1999 who reported that the liver weights from rats injected with alloxan were significantly greater than the negative control group. Also, the present results agreed with that found by Chai et al., 2008 who reported that the kidney weights from rats given alloxan were significantly increased compared to control group.

The bioactive effects of different levels of vitamin $\mathrm{E}$ on calcium and phosphorus in bone of diabetic rats are presented in Table (3). Data showed that $\mathrm{Ca}$ concentration in bone of normal rats fed on basal diet was $0.03 \pm 0.01 \mathrm{mg} / \mathrm{dl}$, while as a result of inducing diabetes in rats (+ve control), bone calcium concentration was reduced significantly with a mean value of $0.01 \pm 0.02 \mathrm{mg} / \mathrm{dl}$ compared with the un-diabetic normal control rats. Data showed that when the diet was supplemented with vitamin $\mathrm{E}, \mathrm{Ca}$ concentration in bone was improved according to the supplemented level .However, the highest concentration of $\mathrm{Ca}$ in bone showed when rats were fed on diet supplemented with the highest level of vitamin $\mathrm{E}(1.5 \%)$ having a mean value of $0.04 \pm 0.01 \mathrm{mg} / \mathrm{dl}$.

Concerning phosphorus concentrations in bone, results showed significant reduction in its concentration as increasing vitamin $\mathrm{E}$ supplementation level in the diet. Results in Table (3) illustrated that phosphorus concentration in bone of diabetic rats (+ve control) was reduced significantly with a mean value of $0.01 \pm 0.01 \mathrm{mg} / \mathrm{dl}$ compared with the normal control group fed on basal diet without supplementation $(0.06 \pm 0.03 \mathrm{mg} / \mathrm{dl})$. When diet was supplemented with vitamin E, phosphorus concentration in bone was increased significantly with the lowest level of supplementation with a mean value of $0.04 \pm 0.02 \mathrm{mg} / \mathrm{dl}$ as compared with the +ve control group. 8

Table3. Effect of Different Levels of Vitamin E on Bone Concentration of Calcium and Phosphorus of Diabetic Rats

\begin{tabular}{|c|c|c|c|}
\hline \multicolumn{2}{|c|}{ Groups } & \multicolumn{2}{|c|}{ Minerals Concentration of Bone } \\
\hline & & Calcium (mg/dl) & Phosphorus (mg/dl) \\
\hline \multirow{2}{*}{ } & $\begin{array}{l}\text { Group(1) } \\
\text { (-ve) }\end{array}$ & $\begin{array}{c}\mathrm{a} \\
0.03 \pm 0.01\end{array}$ & $\begin{array}{c}\mathrm{a} \\
0.06 \pm 0.03\end{array}$ \\
\hline & $\begin{array}{c}\text { Group(2) } \\
(+\mathrm{ve})\end{array}$ & $\begin{array}{c}c \mathrm{c} \\
0.01 \pm 0.02\end{array}$ & $\begin{array}{c}\mathrm{d} \\
0.01 \pm 0.01\end{array}$ \\
\hline \multirow{3}{*}{ 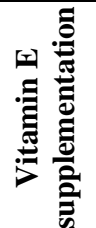 } & $\begin{array}{c}\text { Group(3) } \\
0.75 \%\end{array}$ & $\begin{array}{c}\mathrm{b} \\
0.03 \pm 0.01\end{array}$ & $\begin{array}{c}\mathrm{ab} \\
0.04 \pm 0.02\end{array}$ \\
\hline & $\begin{array}{c}\text { Group (4) } \\
1 \%\end{array}$ & $\begin{array}{c}c \\
0.01 \pm 0.03\end{array}$ & $\begin{array}{c}c \\
0.02 \pm 0.01\end{array}$ \\
\hline & $\begin{array}{c}\text { Group(5) } \\
1.5 \%\end{array}$ & $\begin{array}{c}\mathrm{a} \\
0.04 \pm 0.001\end{array}$ & $\begin{array}{c}\mathrm{b} \\
0.03 \pm 0.01\end{array}$ \\
\hline
\end{tabular}


*Mean values are expressed as means \pm SE. Means with different superscript letters in the column are significantly different at $(\mathrm{P}<0.01)$.

In regard to effects of vitamin $\mathrm{E}$ on calcium, phosphorus in bone of diabetic rats this study showed that calcium concentration of diabetic rats fed on basal diet (+ve control group) was significantly decreased compared to normal rats fed on basal diet (-ve control).The effect could be explained by what reported by Okuna et al., 1991 who stated that diabetes mellitus is known as one of the major causes of low turnover osteopenia. Some other studies confirmed this result, they found that diabetes is often associated with reduced bone mass and delayed fracture healing in human (Loder, 1988 and Heap et al., 2004).

The bioactive effect of different levels of vitamin $\mathrm{E}$ on concentration of iron in bone and

Table4. Effect of Different Levels of Vitamin E on Concentration of Iron in bone and Serum Glucose Concentration of Diabetic Rats

\begin{tabular}{|c|c|c|c|}
\hline \multicolumn{2}{|c|}{ Groups } & \multirow{2}{*}{$\begin{array}{c}\text { Bone Iron (Fe) } \mathbf{m g} / \mathbf{d l} \\
\mathrm{a} \\
0.36 \pm 0.11\end{array}$} & \multirow{2}{*}{$\begin{array}{c}\text { Glucose } \mathbf{m g} / \mathbf{d l} \\
\mathrm{d} \\
97.54 \pm 2.08\end{array}$} \\
\hline$\overline{0}$ & $\begin{array}{l}\text { Group(1) } \\
(-\mathrm{ve})\end{array}$ & & \\
\hline อี & $\begin{array}{c}\text { Group(2) } \\
(+\mathrm{e})\end{array}$ & $\begin{array}{c}\mathrm{d} \\
0.09 \pm 0.07\end{array}$ & $\begin{array}{c}\mathrm{a} \\
145.35 \pm 1.89\end{array}$ \\
\hline \multirow{3}{*}{ 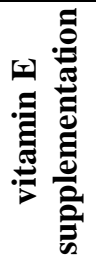 } & $\begin{array}{c}\text { Group(3) } \\
0.75 \%\end{array}$ & $\begin{array}{c}\mathrm{b} \\
0.20 \pm 0.04\end{array}$ & $\begin{array}{c}\mathrm{e} \\
95.93 \pm 1.39\end{array}$ \\
\hline & $\begin{array}{c}\text { Group(4) } \\
1 \%\end{array}$ & $\begin{array}{c}\mathrm{d} \\
0.15 \pm 0.04\end{array}$ & $\begin{array}{c}c \mathrm{c} \\
106.45 \pm 1.84\end{array}$ \\
\hline & $\begin{array}{c}\text { Group(5) } \\
1.5 \%\end{array}$ & $\begin{array}{c}c c \\
0.10 \pm 0.03\end{array}$ & $\begin{array}{c}\mathrm{b} \\
138.6 \pm 2.50\end{array}$ \\
\hline
\end{tabular}

*Mean values are expressed as means \pm SE. Means with different superscript letters in the column are significantly different at $(\mathrm{P}<0.01)$.

It has been shown that vitamin $\mathrm{E}$ improves bone quality in the aged but not in young adult male mice (Arjmandi et al., 2002). It was also reported that an adequate intake of vitamin $\mathrm{E}$ and vitamin $\mathrm{C}$ was protective against the hip fracture risk in female smokers (Melhus et al., 1999).

In general, results of our study showed that the lowest level of vitamin E supplementation corrected blood glucose level of diabetic rats .This result was in agreement with Garrett et al., 1990, Ima-Nirwana et al., 1999 and Fardoun, 2007.They reported that vitamin $\mathrm{E}$ is an antioxidant that is thought to play an important role in protecting cells against the effects of free radicals, which can damage cells and may contribute to the development of diabetes. However, these results disagreed with what stated by Arjmandi et al., 2002 who concluded ARC Journal of Nutrition and Growth serum glucose concentration of diabetic rats are presented in Table (4). Regarding iron $(\mathrm{Fe})$ concentration in bone data illustrated that $\mathrm{Fe}$ concentration varied with the tested level of vitamin E supplementation. The highest concentration of $\mathrm{Fe}$ concentration increased significantly with a mean value of $0.20 \pm 0.04$ when supplemented with vitamin $\mathrm{E}$ at $0.75 \%$ level.

Results of this study showed that vitamin E supplemented at the lowest level $(0.75 \%)$ induced significant reduction in blood glucose level. However, when diet was supplemented with vitamin $\mathrm{E}$ at levels $1 \%$ and $1.5 \%$, blood glucose levels were increased significantly with a mean value of $106.45 \pm 1.84 \mathrm{mg} / \mathrm{dl}$ and $138.6 \pm 2.50 \mathrm{mg} / \mathrm{dl}$, respectively, compared to the normal control rats received basal diet only. that there is no any established benefit for antioxidant such as vitamin $\mathrm{E}$.

The histopathological examination of liver and kidney of diabetic rats fed on diet supplemented with vitamin $\mathrm{E}$ at three levels of intake showed slight granularity of cytoplasm of hypatocytes and apparent normal renel parenchyma compared with the control group. However, few available literatures regarding the effect of vitamin $\mathrm{E}$ supplementation on histopathological changes in these organs could be obtained.

Figures (1-2) show the histopathological examination of liver tissues. Liver of normal rats (-ve control group), fed on basal diet only, showed normal histological structure of hepatic lobule (Figure 1). When rats were become diabetic (+ve control group) liver showed vacuolar degeneration of hepatocytes and pyknosis of hepatocytic . Meanwhile, when rats were ingested vitamin $\mathrm{E}$ in the diet, at the lowest level (Figure 3), liver showed slight granularity of the cytoplasm of hepatocytes. Microscopical 
examination of liver of rat who received $1.5 \%$ of vitamin $E$ revealed granularity of the cytoplasm of hepatocytes.

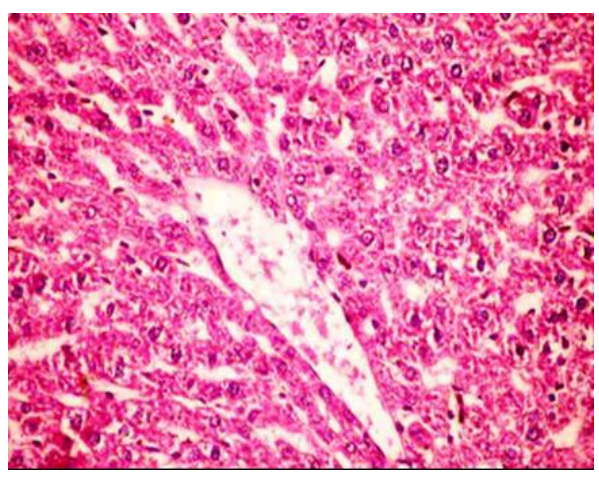

Fig1. Liver of rat from normal control group (-ve) showing the normal histological structure of hepatic lobule. (H and Ex 200)

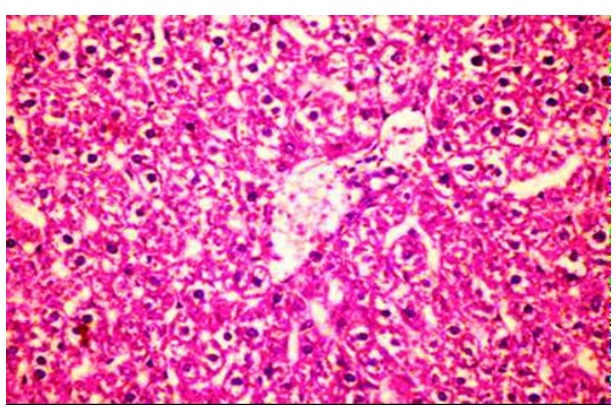

Fig2. Liver of diabetic rats (+ve) showing vacuolar degeneration of hepatocytes and pyknosis of hepatocytic

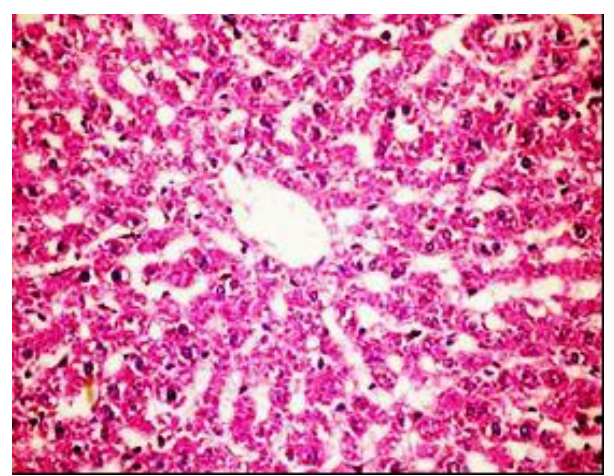

Fig3. Liver of rat having $0.75 \%$ of vitamin $E$ showing slight granularity of the cytoplasm of hepatocytes $(H$ and $E X 200$ ).

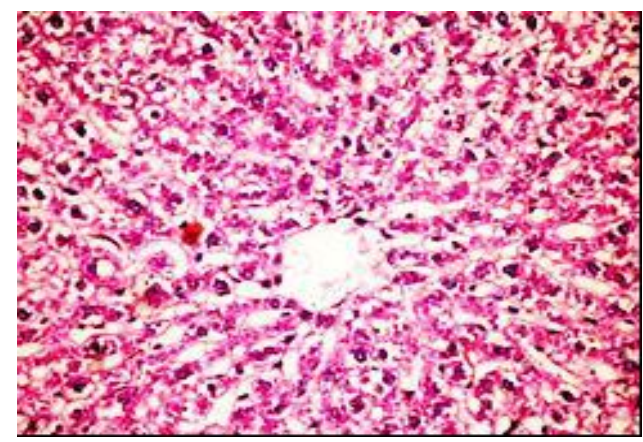

Fig4. Liver of rat having $1 \%$ of vitamin E showing granularity of the cytoplasm of hepatocytes. ( $H$ and Ex 200)

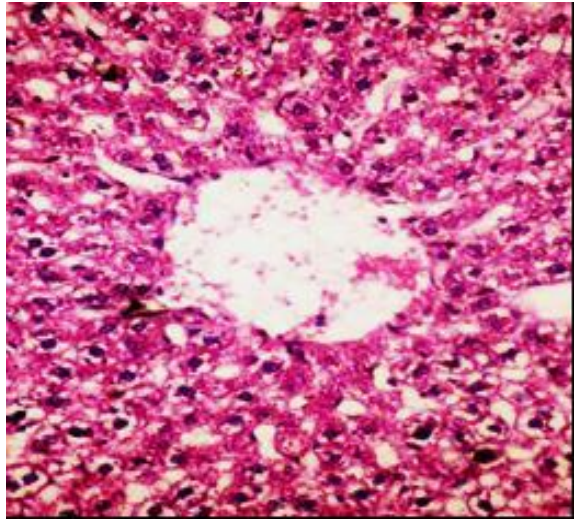

Fig5. Liver of rat having $1.5 \%$ of vitamin $E$ showing granularity of the cytoplasm of hepatocytes. ( $H$ and $E$ $x$ 200).

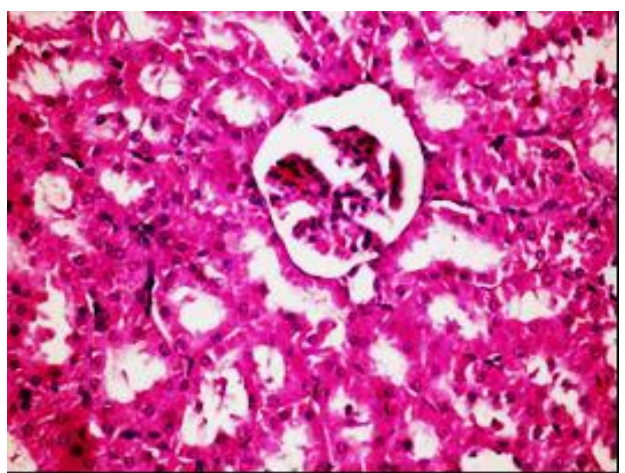

Fig6. Kidney of normal control (-ve) group showing the normal histological structure of renel parenchyma. (H and Ex 200).

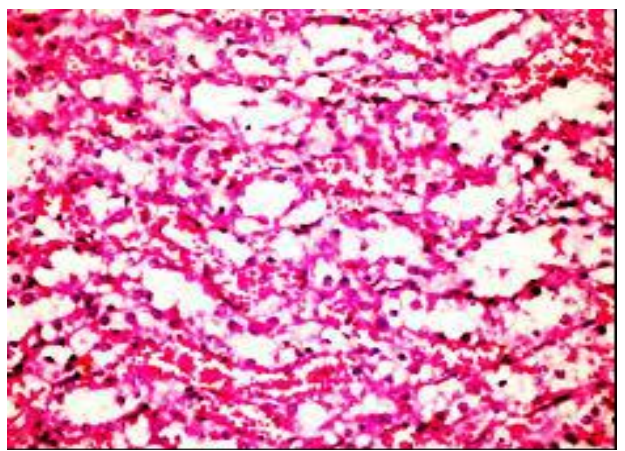

Fig7. Kidney of (+ve) control rats showing vacuolations of renel tubular epithelium and congestion of intertubular blood vessels. $(H$ and $E x$ 200)

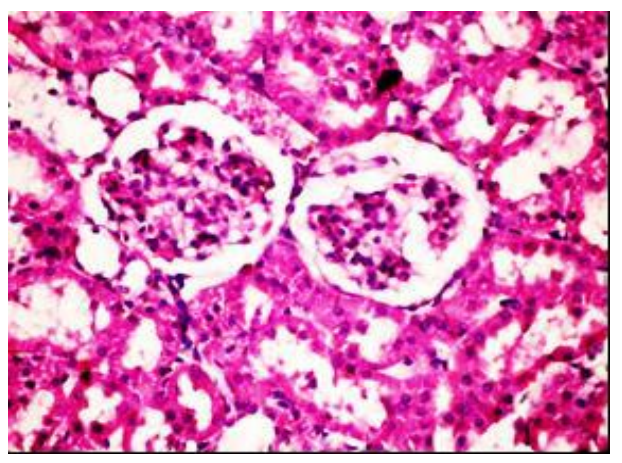

Fig8. Kidney of rats having level 1 showing apparent normal renel parenchyma. (H and $E x$ 200) 


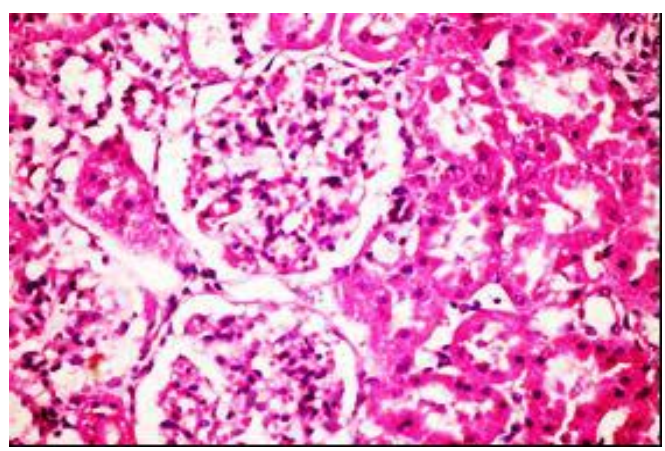

Fig9. Kidney of rats having level 2 showing hypertrophy and congestion of glomerular tufts. (H and $E x 200$ )

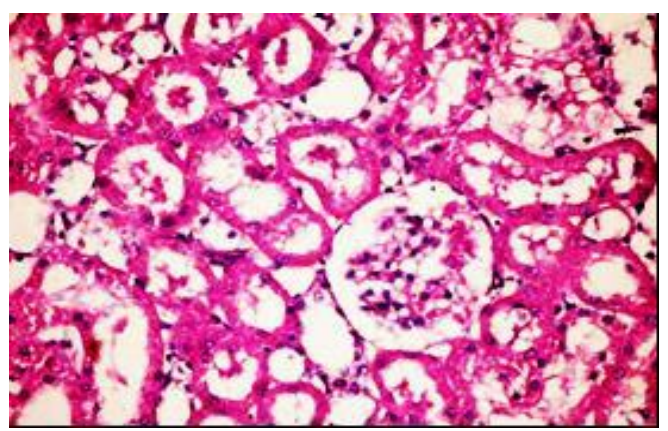

Fig10. Kidney of rats having level 3 showing vacuolations of endothelial lining glomerular tuft and presence of eosinophilic protein cast in the lumen of renel tubules. ( $H$ and $E x 200$ )

In the present study, the histopathological examination of liver and kidney of normal rats showed normal histopathological structure of liver as well as kidneys. When rats were become diabetic (+ve control rats) liver showed vacuolar degeneration of hepatocytes and pyknosis of hepatocyte. When rats were ingested diet supplemented with vitamin E especially at the lowest levels $(0.75 \%$ and $1 \%)$ leads to improve the degeneration changes of liver and this result get along with that shown by Hypponen, 2004.

\section{REFERENCES}

[1] Arjmandi B.H., Juma S., Beharka A., Bapna, M.S., Akhter M and Meydani S. N. (2002): Vitamin E improves bone quality in the aged but not in young adult male mice. $\mathrm{J}$ of Nutritional Biochemistry 13:543-549.

[2] Aruoma, O.I., Neergheen, V .S., Bahorun, T., and Jen, L.S., (2007): Free Radicals, Antioxidants and Diabetes, Embryopathy, Retinopathy, Neuropathy, Nephropathy and Cardio-vascular Complications. Neuroembryol Aging 4:117-137.

[3] Ball, G.F.M., (2004): Vitamin E. In: Vitamins. Their Role in the Human Body. Blackwell Publishing, 234-255.

[4] Carlton, H., (1979): in "Histological Techniques", 4th Edition, London, Oxford University press, New York, USA.
[5] Chai S.C., Wei C.I.,Brummel-Smith K., and Arjmandi B.H.,(2008): The role of vitamin E in reversing bone loss. Aging Clin Exp Res.20 (6):521-527.

[6] Champon D.,Castilla R., and Campdell J.A.,(1959): Evaluation of Protein in Food .Determination of protein and feed efficiency ratio ., Can.Biochem. Physol., 37:679-686.

[7] Devereux G., Turner S.W., Craig L.C.A., McNeil G., Martindale S. and Harbour P.J.,(2006):Low maternal vitamin $\mathrm{E}$ intake during pregnancy is associated with asthma in 5-year old children .Am J Respir Crit Care Med: 174:499-507.

[8] Douillet C., Tabib A., Bost M., Accominotti M., Borson C.F., and Ciaratti M., (1996): A selenium supplement associated or not with vitamin $\mathrm{E}$ deleys early renal lesions in experimental diabetes in rats .Proced .Soc .Exper Biol.Med., 211(4), 323-331.

[9] El-Merzabani, M.M., El- Aaser. A.A., and Zakhary, N.I., (1977): J. Clin. Chem. Clin. Biochem. 15:715 - 718 .

[10] EL-Miedany Y. M., EL Gaafary S., and ELBaddini M.A., (1999): Osteoporosis in older adults with non-insulin dependent diabetes Mellitus: Is it sex related? Clinical and Experimental Rheumatology 17:561-567.

[11] Fardoun, R.Z., (2007): The use of vitamin E in type 2 diabetes mellitus.Clin Exp Hypertens. 29 (3): $135-48$.

[12] Garrett, I.R., Boyce B.F., Oreffo R.O., Bonewald I., Poser J., and Mundy G.R.,(1990): Oxygen free radicals stimulate osteoclastic bone resorption in rodent bone in vitro and in vivo .Jclin Invest 85:632-639.

[13] Gindler M. King J.D. (1972): Am. J. Clin. Path. 58,376 .

[14] Halliwell, B., Rafter, J., and Jenner, A., (2005): Health promotion by flavonoids, tocopherols, tocotrienols, and other phenols: direct or indirect effects? Antioxidant or not? Am J Clin Nutr, 81 Suppl: 268-76.

[15] Hamada, Y., Fujii, H., and Fukagawa, M., (2009): Role of oxidative stress in diabetic bone disorder .Department of Nutrition, Kobe University Hospital, Kobe 650-0017, Japan.

[16] Hayward, A.R., Shriber M., and Sokol, R., (1992): Vitamin E supplementation reduces the incidence of diabetes but not insulitis in NOD mice. J Lab Clin Med.; 119:503-507.

[17] Heap J., Murray M.A., Miller S. C., Jalili T., and Moyer-Mileur L.J., (2004): Alterations in bone characteristics associated with glycemic control in adolescents with type 1 diabetes mellitus. J Pediatr 144:56-62.

[18] Herrera, and Barbas, C., (2001): Vitamin E: action, metabolism and perspectives.Journal of physiology and biochemistry 57 (2): 43-56. Doi: 10.1007/BF03179812. PMID 11579997. 
[19] Hypponen E., (2004): Micronutrients and the risk of type1 diabetes: vitamin $\mathrm{D}$, vitamin $\mathrm{E}$, and nicotinamide. Nutr Rev.; 62:340-347.

[20] Ima-Nirwana, S., Kifiah, A., Sariza, T, Gapor, M.T.A., and Khalid, B.A.K., (1999): Palm vitamin $\mathrm{E}$ improves bone metabolism and survival rate in thyrotoxic rats. General Pharmac 32:621-626.

[21] Kaplan, L.A., Glucose. Kaplan, A., et al. (1984): Clin Chem The C.V. Mosby Co. St Louis. Toronto. Princeton, 1032-1036.

[22] Loder, R.T., (1988): The influence of diabetes mellitus on the healing of closed fractures. Clinical Orthhop 232:210-216.

[23] Melhus, H., Michaelsson, K., Holmberg, L., Wolk, A., and Ljunghall, S., (1999): Smoking, antioxidant vitamins and the risk of hip fracture. J Bone Miner Res 14:129-135.

[24] Okuna Y., Nishizawa Y., and Sekiya k., (1991): Total and regional bone mineral content in patients with non-insulin dependent diabetes mellitus. J Nutr Sci Vitaminol 37: S43-S49.

[25] Reeves, P., Nielsen, F., and Fahmy, G., (1993): AIN-93. Purified diets for laboratory rodents: Final reports of the American Institute of Nutrition adhoe wriling committee of reformulation of the AIN-76 A Rodent Diet. J. Nutr. 123, Pp. 1939-51.
[26] Risérus, U., Willett, W.C., and Hu, F.B., (2009): Dietary fats and prevention of type 2 diabetes. Progress in Lipid Research 48 (1): 44-51. doi:10.1016/j.plipres.2008.10.002. MID 19032965.

[27] Rother, K.I., (2007): Diabetes treatmentbridging the divide .The New England Journal of Medicine 356 (15): 1499-501. doi:10.1056/NEJMp078030. PMID 17429082.

[28] SAS. (2006): Statistical Analysis System, SAS User's Guide: statistics. SAS Institute inc. Editors, Cary, NC.

[29] Traber, M.G., and Packer, L., (1995): Vitamin $\mathrm{E}$ : Beyond antioxidant function. Am J Clin Nutr, 62:1501S-9S.

[30] Trinder, P., (1969): Ann Clin Biochem. 6 2433.

[31] Van Campenhout, A, Van, Campenhout C., Lagrou, A.R., Abrams, P., Moorkens, G., Van, Gaal L., and Manuel-y-Keenoy, B., (2006): Impact of diabetes mellitus on the relationships between iron-, inflammatory- and oxidative stress status. Nov-Dec; 22(6):444-54.

[32] Wild, S., Roglic, G., Green, A., Sicree, R., and King, H., (2004): Global prevalence of diabetes. Estimates for 2000 and projections for 2030". Diabetes Care (5)1047 53. doi:10.2337/diacare.27.5.1047.PMID 15111519

Citation: Hoda S. Ibrahim, Zahraa E. Sayed, and Hany G. El Masry. Effect of Vitamin E Supplementation on Some Minerals in Diabetic Rats. ARC Journal of Nutrition and Growth. 2017; 3(2):19-26. Doi: dx.doi.org/10.20431/2455-2550.0302004.

Copyright: (C) 2017 Authors. This is an open-access article distributed under the terms of the Creative Commons Attribution License, which permits unrestricted use, distribution, and reproduction in any medium, provided the original author and source are credited. 